\title{
DIE VRAAG NA EN AANBOD VAN VERPLEEGKUNDIGES IN SUID AFRIKA
}

\author{
Marie E Muller
}

\section{UITTREKSEL}

Die dreigende krisis in die verpleegberoep, veral in die openbare sektor, het tot 'n nasionale ondersoek aanleiding gegee wat deur die Minister aan die Adviserende Komitee vir Gesondheidsake opgedra is. ' $n$ Nasionale verpleegmannekrag-analise is by wyse van ' $n$ be. skrywende opname deur privaat-konsultante uitgevoer. 'n Verpleegkundige/bevolkingsratio van 1:416 is dew die Swid-Afrikaanse Raad op Verpleging aanbeveel en deur die AKG aanvaar. Die aanvraag oorskry tans die aanbod wat beteken dat 'n reële jaarlikse studenteuitset van 4000 benodig word Die ondersoek het verder aan die lig gebring dat slegs $65 \%$ van die verpleegkollege kapasiteit tans benut word en dat 'n potensiële aanbod van matrikulante tans slegs 3300 per jaar beloop. Belangrike aanbevelings sluit 'n aktiewe bemarking van die beroep in, die infosering van 'n verpleegkundige/bevolkingsratio van 1:416, asook die toepaslike vermeerdering van paste vir studente, dosente en kliniese verpleegkundiges.

\section{ABSTRACT}

The threatening crisis in the nursing profession, especially in the public sector, led to a na. tional investigation that was directed to the HMAC. A national nursing manpower analysis was undertaken by private consultants by means of a descriptive survey. A registered nurse/population ratio of 1:416 was recommended by the Sowh African Nursing Council and accepted by the HMAC. The demand presently exceeds the supply and an actual an. nual student oulput of 4000 is required. It was also emphasized that only $65 \%$ of the college capacities are being utilised and a potential supply of matriculants amounts to 3300 p.a. Important recommendations include active marketing of the profession, phasing in of a registered nurse/population ratio of 1:416, as well as an appropriate increase of posts for students, tutors and clinical nurses.

\section{INLEIDING}

Daar is toenemende aanduidings van ' $n$ groeiende tekort aan geregistreerde verpleegkundiges en vroedvroue in Suid-Afrika en terselfdertyd ' $n$ kommerwekkende toename in die intensiteit van dienste wat hoofsaaklik deur die professionele verpleegkundige gelewer word. Verpleging is dus 'n arbeidsintensiewe praktyk wat nie net die nodige hoeveel heid praktisyns benodig nie, maar ook verpleegkundiges wat 'n hoe gehal teverpleging handhaaf sodat ons met trots aan die gesondheidsbehoeftes van die land, as waardige lede van die multiprofessionele gesondheidspan, kan voldoen.

Die tekort aan verpleegkundiges is ' $n$ wêreldwye probleem en daar is ' $n$ toename in aanvraag (Friedman, 1990: 2977). Die Verenigde State van Amerika toon ook 'n styging in vakante poste: " ... the American Nurses Association (ANA) reported in mid1990 that nursing homes had an average 18,9\% vacancy rate" (Friedman, 1990:2977). Dit blyk ook dat die behoud van verpleegkundiges 'n probleem is. Die jaarlikse personeelomset betreffende geregistreerde verpleegkundiges in Amerika, was $20 \%$ in akute sorginstellings en in sommige state word pogings aangewend om die aanvraag na verpleegkundiges te verminder ten einde stabiliteit te bevorder (Frieciman, 1990:2977). Suid-Afrika ervaar ook tans 'n groter aanvraag na verpleegkundiges in 'n tydperk waar die beroep 'n daling in die groeikoers beleef.

$\mathrm{Na}$ aanleiding van probleme in die beroep het die Suid-Afrikaanse Verpleegstersvereniging (SAVV) in Julie 1989 die dreigende krisis in die verpleegberoep, veral in die openbare sektor, onder die aandag van die Minister gebring. Die SAVV (1989) het 'n beroepsagterstand, asook interne onewewigtigheid in die dienste, as vernaamste probleme in 'n memorandum uitgelig. Omdat verpleegkundiges se salarisse in die staatsdiens nie markverwant is nie, lei dit tot 'n algemene agterstand wat reflekteer word in verskeie probleme.

Die probleme, wat tot 'n nasionale ondersoek deur die Adviserende Komitee vir Gesondheidsdienste (AKG) gelei het, is kortliks soos volg:
- dalende studentegetalle van gemiddeld $6 \%$ per jaar vanaf 1984-1988, wat dui op 'n onvermox om skoolverlaters vir die verpleegberoep te werf, of dat genoeg fondse nie voorsien word om in die behoeftes te voldoen nie;

- 'n vakaturestand van ongeveer $20 \%$ in die totale verpleegpersoneelvoorsiening wat progressief maandeliks verswak, tot $30 \%$ waar nuwe privaathospitale geopen het;

- 'n hoe personeelomset wat moontlik toegeskryf kan word aan nie-markverwante salarisse, swak oortydbesoldiging, onbuigsame diensure en burokratiese bestuursomstandighede;

- 'n verlies an kliniese kundiges in die praktyk as gevol $g$ van ondoeltreffende bevorderingsmoontlikhede vir hierdie spesialis;

- afwesigheid van 'n eiesoortige en toepaslike dosente-struktuur aan verplegingskolleges, met gevolglike sub-optimale benutting van kolleges, ' $n$ verskraling van dienste en verswakking van die gehalte van pasientsorg (SAVV, 1989).

Die verpleegkrisis in die openbare sektor het wye mediadekking gedurende die laaste helfte van 1989 verkry en kan 'n negatiewe invloed op die werwing van nuwe rekrute hê.

Die Minister het die vertoa van die SAVV (1989) oor besoldiging en diensvoordele na die kommissie vir Administrasie verwys en die Adviserende Komitee vir Gesondheidsake (AKG) versoek om, by wyse van 'n spesiale ondersoekkomitee, ondersoek in te stel na die krisis in die verpleegberoep. Verskeie ondersoeke is geloods, waarin onder meer, 'n nasionale analise van die geregistreerde verpleegtaakmag uitgevoer is.

Die doel met hierdie ondersoek was om 'n analise betreffende die vraag na en aanbod van die verpleegkundige in Suid-Afrika, selfregerende en nasionale state uitgesluit, binne die raamwerk van die situasie in die Republiek van Suid-Afrika te maak.

\section{TERMINOLOGIE}

Verpleegkundige Die verpleegkundige verwys na die professionele persoon wat by die Suid-Afrikaanse Raad op Verpleging as verpleegkundige geregistreer is. 
Vraag

Die behoefte aan verpleegkundiges in SuidAfrika, die selfregerende en nasionale state (TBVC-lande) uitgesluit.

Aanbod

Die hoeveelheid beskikbare verpleegkundiges (reèl en potensieel) in Suid-Afrika.

\section{NAVORSINGSMETODOLOGIE}

'n Beskrywende opname ten opsigte van die nasionale verpleegtaakmag is gedurende Augustus 1989 - Maart 1990 uitgevoer. Die totale geregistreerde verpleegtaakmag in Suid. Afrika, selfregerende en nasionale state uitgesluit, het as teikenpopulasie gedien. Gesondheidsdiensorganisasies, beide in die openbare en privaatsektor, het as gesondheidsdiens-ontledingseenhede gedien.

'n Oorhoofse ondersoekkomitee is aangestel met verteenwoordiging vanuit die AKG; Direkteur/Adjunk-Direkteur Verplegingsdienste vanuit al die provinsies, asook Eie Sake; die SAVV; Suid-Afrikaanse Raad op Verpleging (SARV), asook bestuurskundiges vanuit die Departement van Nasionale Gesondheid en Bevolkingsontwikkeling (NGBO), Transvaalse Provinsiale Administrasie en Tesourie. 'n Totaal van twaalf lede, met die Direkteur Generaal (NGBO) as voorsitter, was verantwoordelik vir die ondersoek.

Die ondersoekkomitee het tydens sy eerste vergadering in Augustus 1989 besluit om die ondersoek aan verskeie taakgroepe op te dra. Die taakgroep verantwoordelik vir die ondersoek na die verpleegtaakmag het bestaan uit vier lede, te wete 'n bestuurskundige van die NGBO, direkteur verpleegdienste NGBO asook Eie Sake, en 'n verteenwoordiger van die SAVV.

'n Privaatnavorsingsfirma, naamlik Pim Goldby Bestuurskonsultante, is betrek. Die lede van die AKG-taakgroep het as 'n valideringskomitee vir die ondersoek gedien. Hierdie valideringskomitee het met die

navorsingskonsultante die opdrag uitgeklaar, asook die navorsingstegnieke, teiken- en steekproefpopulasies. Weeklikse, twee weeklikse of maandelikse vergaderings/gesprekvoering is vanaf November 1989 tot die einde Maart 1990 met die konsultante gehou. Die vordering en probleme deur die konsultante ondervind, is bespreek en die vorderingsresultate is gevalideer.

Tydens hierdie ondersoek, betreffende ' $n$ verpleegmannekraganalise, is verskeie bronne geildentifiseer en die daca is hoofsaaklik by wyse van persoonlike onderhoudvoering, telefoniese onderhoudvocring, asook via die gesondheidsowerhede ingewin. Die primêre inligtingsbronne was die onderskeie gesondheidsdiensowerhede, RGN, Sentrale Statistiese Dienste, Buro vir Marknavorsing (Unisa); die Nasionale Instituut vir Personeelnavorsing, die Departement van Nasionale Op- voeding, SARV, SAVV en verteenwoordigers van die privaatsektor.

Die teikendatum vir die voltooiing van die ondersoek en inhandiging van die finale navorsingsverslag was 31 Maart 1990. 'n

Driedaagse werkswinkel is gedurende April 1990 deur die AKG-ondersoekkomitee gehou waartydens al die navorsingsverslae betreffende die ondersoek na die krisis in die verpleegberoep ontleed is. Die prioriteitprobleme is geidentifiseer en aanbevelings is geformuleer ter voobereiding van die finale verslag wat aan die Minister voorgelê is.

\section{RESULTATE}

Die ondersoek betreffende die vraag na en aanbod van verpleegkundiges in Suid-Afrika het die volgende feite betreffende die vraag en aanbod van geregistreerde verpleegkundiges uitgelig. Die huidige aanbod van geregistreerde verpleegkundiges sal eerstens toegelig word, vervol gens die vraag na hierdie kategorie en laastens die implikasies.

Die huidige aanbod van geregistreerde verpleegkundiges

\section{Reële aanbod}

Daar is op 31 Desember 1989 ongeveer 75000 geregistreerde verpleegkundiges op die registers van die Suid-Afrikaanse Raad op Verpleging (SARV, 1989) wat 'n verpleegkundige/bevolkingsratio van 1:422 verteenwoordig (SARV, 1990: 5).

'n Verdeling van die getalle sien soos volg daaruit: Die nasionale en selfregerende state het ongeveer 11000 wat ons met 'n totaal van 64000 laat. Die openbare sektor het tans 30000 , privaatsektor-hospitale 12000 , privaatsektor ander, bv industrie, spreekkamers, privastpraktisyns, ens., 10000, nie-praktiserende verpleegikundiges ' $n$ verstommende 7000 en verpleegkundiges wat wel geregistreer is maar ander beroepe praktiseer, veral in die farmaseutiese bedryf, 5000 (vergelyk tabel een). Dit is opmerklik dat $19 \%$ van die totale geregistreerde taakmag tans nie verpleeg nie (Goldby, 1990: 2.4-2.10). Die beskikbare ratio verpleegkundiges, bereken op die 64000 , is dus 1:458 (SARV, 1990: 5).

\section{Potensiële aanbod}

Verpleging is ' $n$ vroue-beroep en derhalwe sal slegs na die potensie̋le ekonomies aktiewe vroulike matrikulante gekyk word. 'n Analise van hierdie gegewens dui daarop dat, alhoewel daar ' $n$ totaal van 67000 vroulike matrikulante (tussen die ouderdom 15-19 jaar) vir 1990 beskikbaar gaan wees, slegs 27000 met post-sekondêre opleiding sal voortgaan (vergelyk tabel twee). Ongeveer een derde van alle matrikulante ondergaan ' $n$ eenjaaropleiding (vergelyk tabel drie). Dit laat ons met 'n totaal van $58 \%$ wat moontlik 'n vierjaarkursus sal volg waarvan slegs 3300 (15\%), met in agneming van die kompeterende beroepe, vir verpleegopleiding, op grond van historiese analises, beskikbaar sal wees (Goldby,
1990: 3.4-3.6). Ongeveer $30 \%$ van alle vroulike matrikulante (ekonomies aktief) volg 'n sekretariële kursus en 'n verdere $11 \%$ volg 'n matrikulasie plus 'n twee- of driejaarkursus. Vanuit die oorblywende 58\% wat moontlik 'n vierjaarkursus na matriek sal volg, is die kompetisie vir verpleegopleiding hoofsaaklik in die onderwys wat ongeveer $40 \%$ van die beskikbare vroulike matrikulante sal werf (Goldby, 1990: bylae 3.3 ).

Die beskikbare potensielle matrikulante is soos volg bereken: $37 \%$ van 60000 matrikulante (wat geslaag het) $=22200$ potensièle kandidate, $15 \%$ van $22200=3330$. Die aanname kan dus gemaak word dat die verplegingsberoep ongeveer $5-6 \%$ van die vroulike matrikulante kan werf (Goldby, 1990: 3.7). Hierdie berekeninge berus op die aanname dat indien die 57000 vroulike matrikulante gedurende 1987 met 5,5\% toeneem, (volgens historiese analises) behoort daar in 1990 ongeveer 67000 beskikbaar te wees waarvan ongeveer 7000 nie matriek gaan slaag nie, gebaseer op die $40 \%$ slaagsyfer van swart matrikulante (Goldby, 1990: 3.3).

Tendense vir die jare 1990-2010 (vergelyk tabel vier) toon dat daar ' $n$ toename van swart matrikulante vanaf $43 \%$ tot $67 \%$ sal wees, kleurlinge vanaf $7 \%$ tot $11 \%$ sal toeneem, en dat die Asièrs min of meer stabiel sal bly, terwyl die blanke matrikulante van $43 \%$ van die totaal sal afneem na $17 \%$. Die geprojekteerde getal vroulike matrikulante vir die jaar 2010 sal ongeveer 140000 wees (Goldby, 1990 : 3.2-3.3).

Om die potensiěle aanbod van geregistreerde verpleegkundiges in die nabye toekoms te bereken, is dit nodig om die huidige stand van verpleegopleiding te ontleed. 'n Analise van die huidige gevulde en vakante studenteposte, in beide kolleges en universiteite, toon dat daar tans 'n totaal van 12631 poste is (vergelyk tabel vyf) met bykans 3500 (28\%) vakant (Goldby, 1990: 3.8). Drie Transvaalse Universiteite was nie bereid om inligting te verskaf nie.

Die opleidingsinstansies is voorts gevra wat hul maksimum kapasiteit kan wees met hul huidige fasiliteite indien hul dosenteposte gevul is. Dit blyk dat hierdie kapasiteit aansienlik kan vermeerder to ' $n$ totaal van bykans 14500 (vergelyk tabel vyf). Slegs 65\% van die huidige kapasiteit word dus benut. Dit blyk voorts dat slegs die Oranje-Vrystaat 'n betekenisvolle studente waglys-syfer van 1626 het (Goldby, 1990: 3.8).

\section{Beskikbare dosentes}

Die registers van die SARV toon tans ongeveer 2700 geregistreerde dosentes. Ons moet egter in gedagte hou dat die meeste van die verpleegdiensbestuurders $\infty$ ok $\infty$ r 'n onderwyskwalifikasie beskik. 'n Ontleding van die postestand in kolleges en universiteite (vergelyk tabel ses) toon 'n totaal van net meer as 1000 gevulde poste met die grootste tekorte in 
die Oranje-Vrystaat. Dit blyk dat daar 'n total van $14 \%$ vakante poste is (Goldby, 1990 : 3.10).

Die van Wyk-komitee het 'n dosent/studentratio van 1:10 aanbeveel (van Wykkomiteeverslag, 1989). 'n Ontleding van die werklike dosent/studentratio's in verpleegkolleges blyk dat al die kolleges tans binne hierdie norm funksioneer (vergelyk tabel sewe). Indien al die dosenteposte gevul is en die maksimum kapasiteit van elke kollege benut word, sal die kolleges in Transvaal 'n bykans 1:15 ratio hê, met die Kaapprovinsie 1:12, Natal 1:11 en die Oranje-Vrystaat sal die beste daaraan toe wees met ' $n$ ratio van 1:7. Hierdie syfers sluit die universiteite in wat hul totale postestand betreffende die dosentes gegee het maar slegs die postestand vir die basiese vierjaarprogram. Die na-registrasie, asook na-graadse studente is dus nie in berekening gebring nie, wat die dosentestudente verhouding moontlik negatief kan beïnvloed.

\section{HUIDIGE AANVRAAG}

\section{Wêreld Gesondheidsorganisasie}

Die Wêreld Gesondheidsorganisasie (WHO, 1985) propageer een geregistreerde verpleegkundige vir elke 250 van die bevolking in ' $n$ eerste wêreldland en een tot 500 in 'n derde wêreldland. Die nuutste aanbevole norm vir Suid-Afrika is tans $1: 263$, of 38 vir elke 10000 van die bevolking (vergelyk tabel agt), wat net nie haalbaar is nie; vir Suid-Afrika beteken dit tans dus 'n totaal van ongeveer 150000 geregistreerde verpleegkundiges.

\section{Suid-Afrikaanse Raad op Verpleging} Die SARV (1990: 5) stel 'n ratio van 1:416 voor. Hierdie ratio is deur die AKG ondersoekkomitee aanvaar en aanbeveel (AKG, 1990: 44). Om die status quo te handhaaf beteken dit dat jaarliks ongeveer 2000 verpleegkundiges moet kwalifiseer (selfregerende en nasionale state uitgesluit). Vanaf 1995 sal hierdie reêle uitsetsyfer vol gens die bevolkingsgroeisyfer 'n drastiese toenname in aanvraag toon.

\section{Aanvraag volgens openbare sektor}

Die openbare sektor het tans ongeveer 30000 verpleegkundiges op hul diensstaat en reflekteer 'n postevulling van $86 \%$ waarvan die behoefte groter in die kliniese range is. Daar moet in aggeneem word dat 'n groot getal poste gevries is. Daarom het die ondersoekkomitee ook ' $n$ beraamde tekorte analise gedoen wat 'n tekort van ongeveer $30 \%$ in die openbare sektor toon (vergelyk tabel nege). Die totale tekort in die openbare sektor beloop dus tans ongeveer 12000 verpleegkundiges.

'n Analise van die beraamde tekorte in die openbare sektor volgens spesialiteitsareas is ook uitgevoer. Die goedgekeurde poste, volgens die posbenamings professionele verpleegkundige, senior verpleegkundige en hoofverpleegkundige, is aangevra asook die voorgestelde postestand deur die onderskeie provinsiale indiensnemingsowerhede. Hierdie analise toon dat die respondent(e) in Transvaal van mening was dat die professionele verpleegkunde-poste verminder kan word maar ' $n$ betekenisvolle behoefte in die vermeerdering van beide die senior en hoofverpleegkundige poste word aangedui (vergelyk tabel 10). Die Kaapprovinsie ervaar veral 'n tekort in die senior verpleegkundige posvlak en 'n geringe tekort in die hoofverpleegkundige poste. Natal se grootste behoefte blyk in die professionele verpleegkunde posvlak te wees en dit blyk asof die hoofverpleegkundige 'n minimale bestaansreg in hierdie provinsie het. Die behoefte in die Oranje-Vrystaat blyk hoofsaaklik in die posvlak professionele verpleegkundige te wees (Goldby, 1990: 2.72.8).

\section{Aanvraag in die privaatsektor}

Die bestaande aanvraag na verpleegkundiges in die privaatsektor was nie kwantifiseerbaar nie. Gesprekvoering met afgevaardigdes van die privaatsektor het egter daarop gedui dat hulle wel 'n tekort ervaar, veral in die spesialiteitareas soos intensiewe verpleegkunde. 'n Minimale jaarlikse groei van $5 \%$ betreffende beddens in die privaatsektor is voorspel. Die verteenwoordigers het ' $n$ behoefte aan ' $n$ "hospitaal-opgeleide" verpleegkundige uitgespreek, met kennis en vaardighede slegs in algemene verpleegkunde.

\section{Studente-uitvalsyfer}

Die uitvalsyfer tydens opleiding is tans onrusbarend. In die eerste studiejaar is daar nasionaal 'n verlies van $30 \%$, in die tweedejaar $8 \%$ en in die derdejaar $2 \%$ (vergelyk tabel 11). Gedurende die vierde en/of vyfde jaar is daar 'n uitval van gesamentlik $1 \%$. Hierdie syfers verteenwoordig 'n gemiddelde uitval van 37\% (Goldby, 1990: 3.11).

\section{Aftredes}

Die verplegingstaakmag toon 'n verouderende profiel en die gemiddelde aftredesyfer in die openbare sektor is tans $2,2 \%$ teenoor ' $n$ "normale" aftredesyfer in ander beroepe van $1,2 \%$. Dit blyk dus of daar ongeveer 600 verpleegkundiges jaarliks in die openbare sektor aftree. Hierdie getal kan met gemak vermeerder word om 'n nasionale syfer van ongeveer 1000 aan te dui, indien verpleegkundiges in die privaatsektor bygereken word.

\section{Bevolkingsgroei}

Die nasionale bevolkingsgroeisyfer is tans ongeveer $2,3 \%$ wat beteken dat die hoeveelheid verpleegkundiges ook ooreenstemmend moet toeneem om die voorgestelde verpleegkundige/bevolkingsratio te handhaaf. 'n Analise van hierdie gegewens (vergelyk tabel 12) toon dat die Suid-Afrikaanse bevolking vanaf 1990 tot 2010 met ongeveer ses miljoen gaan toencem (Goldby, 1990: 4.3).

\section{IMPLIKASIES}

Daar is tans 64000 verpleegkundiges beskikbaar wat 'n ratio van 1:458 verteenwoordig. Die voorgestelde ratio is $1: 416$ wat dus 'n aanvraag van ongeveer 2000 verplee gkundiges per jaar beteken (selfregerende eri nasionale state uitgesluit).

Die openbare sektor het 'n tekort van 12000 verpleegkundiges wat waarskynlik by wyse van die oorbruggingskursus oorkom sal word. Om in die uitvalsyfer te voorsien sal daar 'n bykomende 3000 studente per jaar ingeneem moet word en 'n bykomende 1000 om die afgetredenes jaarliks te vervang. Dan moet die bevolkingsgroeisyfer van $2,3 \%$ ook nog in berekening gebring word.

Die SARV (1989:11) is van mening dat daar jaarliks ongeveer 4000 studente moet kwalifiseer, met 16000 deurlopend in opleiding. Daar is tans slegs sowat 9500 studente in opleiding, waarvan daar nog heelwat gaan uitval. Die optimale kapasiteit van die kolleges word op 14500 bereken en 'n potensiěle aanbod van matrikulante is slegs 3300 .

Om 'n verpleegkundige/bevolkingsratio van 1:416 te handhaaf, is 2000 afgestudeerdes per jaar nodig. Hierdie syfer vermeerder progressief so drasties dat ons in 1995 'n uitset van bykans 13000 benodig (vergelyk tabel 13 ). Afhangende van die bevolkingsgroeisyfer sal 'n voortdurende vermeerderde uitset van ongeveer 3000 per jaar benodig word (AKG-1990).

Dringende stappe sal onverwyld in werking gestel moet word om studentegetalle drasties te verhoog, die benutting van tans erg onderbenutte opleidingsfasiliteite (insluitende die privaatsektor) te optimaliseer en faktore wat aanleiding gee tot die hoe uitvalsyfer, uit te skakel. Multikulturele opleiding, asook aktiewe werwing, onder beide die vroulike en manlike matrikulante sal prioriteit aandag moet geniet.

'n Vermeerdering in dosenteposte, vanaf 1000 na 1600 is nodig indien ons 16000 studente wil akkommodeer en die aanbevole dosent/studentratio van 1:10 wil handhaaf. Dan wil dit voorkom asof daar 'n uitbreiding in opleidingsfasiliteite benodig word, byvoorbeeld in die vorm van satelietkampusse in die areas waar daar 'n behoefte blyk te wees, soos Oos Transvaal.

\section{AANBEVELINGS}

Die volgende aanbevelings is tersaaklik:

- aktiewe bemarking van die verpleegberoep (AKG, 1990: 35);

- die infasering van 'n verhouding van geregistreerde verpleegkundiges tot die bevolking van 1:416 (AKG, 1990: 44);

- 'n toepaslike vermeerdering van studenteen dosenteposte;

- 'n toepaslike vermeerdering van kliniese poste in die onderskeie provinsies en dien ste;

- Bedinging om meer fondse vir verpleegopleiding (AKG, 1990: 27); 
- suiwering van die geregistreerde verpleegkundige se taak deur die voorsiening van toereikende hulpdienste ten einde optimale benutting van verpleegkundiges te bewerkstellig (AKG, 1990: 27);

- inwerkingstelling van die Van Wykverslag (AKG, 1990: 33);

- dat die bydrae deur die privaatsektor tot verpleegopleiding verhoog word deur formele ooreenkomste tussen die owerheidsen privaatinstellings oor die toepaslike benutting van leergeleenthede en finansiering van verpleegopleiding (AKG, 1990: 40);

- dat vrystelling van ingeskrewe verpleegkundiges wat aan die toelatingsvereistes voldoen vir die oorbruggingskursus, versnel word met die oog op die geprojekteerde behoeftes van geregistreerde verpleegkundiges teen die jaar 2000 (AKG, 1990: 39).

\section{BEPERKINGE}

Die betroubaarheid van die gegewens was afhanklik van die betroubaarheid van die data wat deur die onderskeie owerhede tydens navrae gegee is. Die valideringskomitee moes die privaatkonsultante telkens versoek om hul data te valideer aangesien die groep van mening was dat data telkens foutief was.

Die vernaamste beperking van die studie is die feit dat die selfregerende en nasionale state uitgesluit is wat 'n groot invloed op geprojekteerde getalle kan meebring.

\section{SLOTOPMERKINGS}

Die gehalte van verpleging is afhanklik van 'n toereikende verplegingsmag. Die aanbevelings het ten doel om 'n matige verbetering in die gehalte van die verpleegdiens wat gelewer word te bewerkstellig (in verband met die getalle verpleegkundiges), en om dit binne die realiteite van die Republiek te doen. Die infasering van die aanbevelings sal 'n beraamde R210 miljoen vir die cerste jaar beteken (AKG, 1990: 46).

\section{Erkennings}

Erkenning word hiermee verleen aan:

- Pim Goldby Bestuurskonsultante vir die uitvoering van die navorsing en beskikbaarstelling van die resultate;

* die Departement van Nasionale Gesondheid en Bevolkingsontwikkeling vir toestemming verleen om feite vanuit die AKG-verslag oor die krisis in die verpleegberoep te publiseer;

- die Suid-Afrikaanse Raad op Verpleging vir benutting van data vanuit hul memorandum aan die Minister;

- die Suid-Afrikaanse Verpleegstersvereniging se bestuur vir die vertroue in my gestel om op die ondersoekkomitee te dien.

\section{VERWYSINGS}

AKG-ONDERSOEKKOMITEE 1990: Konsepverslag: Ondersoek na die verpleegberoep. Departement van Nasionale Gesondheid en Bevolkingsontwikkeling: Pretoria (ongepubliseerd).
GOLDBY 1990: Investigation into the manpower situation of nursing staff. Pretoria: Pim Goldby Management Consultants (unpublished).

FRIEDMAN, E 1990: Nursing: new power, old problems. Jama, 264(23), December 1990: 2977-2982.

SUID-AFRIKAANSE RAAD OP VER PLEGING, 1989: Register van opgeleide verpleegkundiges en vroedvroue soos op 31 Desember 1989. Pretoria: SARV.

SUID-AFRIKAANSE RAAD OP VER PLEGING, 1990: Memorandum aan die Minister van Nasionale Gesondheid en Bevolkingsontwikkeling. Pretoria: SARV (ongepubliseerd).

SUID-AFRIKAANSE VERPLEEGSTERSVERENIGING, 1990: Memorandum aan die Minister van Gesondheid insake die krisis in die verpleegberoep. Pretoria: SAVV (ongepubliseerd).

VAN WYKKOMITEE-VERSLAG, 1989 Ondersoek na verpleegopleiding in SuidAfrika. Pretoria: NGBO (ongepubliseerd).

WORLD HEALTH ORGANIZATION, 1985 Annual report, W.H.O. statistics. Geneva: W.H.O.

\begin{tabular}{c}
\hline Marie EMuller \\
D.CUR. (RAU) \\
Medeprofessor RandAfrikaanse Universiteit \\
\hline
\end{tabular}


Tobol 1

Nasionale eanbod van verpleegkundlgee volgene Indienenemingeaktor Meart 1990 (Goldby, 1990: 2.5)

\begin{tabular}{|c|c|c|}
\hline Sektor & Beraumde Aanbod & * Ven Totad \\
\hline Openbare eoktor & 30000 & 47 \\
\hline Privadtsektor (hoepltaal) & 12000 & 18 \\
\hline Pivaratuektor (ander) & 10000 & 15 \\
\hline Nie-praktiserend & 7000 & 11 \\
\hline Nie-verwante & 5000 & B \\
\hline Totad (1) & 64000 & 100 \\
\hline $\begin{array}{c}\text { Selfregerende en } \\
\text { nadionalo State }\end{array}$ & 11000 & \\
\hline SARV Regiter (2) & 75000 & \\
\hline
\end{tabular}

(1) verpleeghundige/bevolkingeratio: 1:458 (4) verpleeghundige/bevolkingeratio: 1:422

Tabel 2

Potensiële eanbod ven vroulike matrlkulente tuesen 15-19 jaer (Goldby, 1990: 3.4)

\begin{tabular}{|c|c|c|}
\hline Jaer & $\begin{array}{l}\text { Potenelale } \\
\text { Getel }\end{array}$ & $\begin{array}{c}\text { Berammde Boakikbere } \\
\text { Cotal PSO }\end{array}$ \\
\hline 1900 & 67521 & 27008 \\
\hline 2000 & 95900 & 38382 \\
\hline 2010 & 138711 & 55484 \\
\hline
\end{tabular}

PSO = Beraamde getal vir poet-sekondbre onderth

Tabol 3

Somtoteal potenaläle eanbod van vroullke matrlkulante 1988 (Goldby, 1990: 3.6 )

\begin{tabular}{|c|c|c|c|}
\hline Opleddingoviak & Totad & $\begin{array}{c}\text { X Alternitiows } \\
\text { Beroeps }\end{array}$ & bernemde \\
\hline Mutriek & 6878 & 2 & 444 \\
\hline Marlek + 1 jacer & 97500 & 30 & 6680 \\
\hline Metriek + 2 jasar & 21270 & 7 & 1554 \\
\hline Matriex + 3 jaar & 11091 & 3 & 888 \\
\hline Metriek + 4 jas & 138711 & 43 & 12878 \\
\hline Verploegatudents & 46883 & 15 & 3300 \\
\hline Totad & 322433 & 100 & 22422 \\
\hline
\end{tabular}

Beraum de hoeveelheid matrikulente in 1888: 875000 $37 \%$ ekonomiea altiewe voultke mat ik dente: 322433

Tabel 4

Beraamde tendense betreffende vroullke matrlkulante tuseen 15-19 jaer (Goldby, 1990: 3.2)

\begin{tabular}{|c|c|c|c|c|c|}
\hline Jear & Adibr & Swart & Kleurling & Blank & Toted \\
\hline 1800 & 4553 & 28924 & 5287 & 28757 & 67521 \\
\hline 2000 & 5247 & 48238 & 8853 & 23470 & 95808 \\
\hline 2010 & 6494 & 93737 & 14583 & 23897 & 138711 \\
\hline & $7-5 \%$ & $43-67 \%$ & $7-11 \%$ & $43-17 \%$ & \\
\hline
\end{tabular}


Tabel 5

Studentevoorelening volgano huldige postestend an mokeimum kepasitolt Meart 1990 (Goldby, 1990: 3.8)

\begin{tabular}{|c|c|c|c|c|}
\hline Provinale & Poote & $\begin{array}{c}\text { Covulde } \\
\text { pote }\end{array}$ & $\begin{array}{l}\text { Maksimum } \\
\text { knpevitelt }\end{array}$ & Woolye \\
\hline Trenovaed & 7048 & 4088 & 7498 & - \\
\hline Kapprovinsle & 3118 & 2488 & 3880 & 182 \\
\hline Netad & 1185 & 000 & 1320 & - \\
\hline Orenlo-Vrystad & 1300 & 1128 & 1620 & 1620 \\
\hline Totad & 12601 & 9172 & 14418 & 1818 \\
\hline
\end{tabular}

Tobol 6

Dle postestand ven dosento 1990

\begin{tabular}{|c|c|c|c|}
\hline \multirow{2}{*}{$\begin{array}{l}\text { Provinale } \\
\text { Treneved }\end{array}$} & \multirow{2}{*}{$\frac{\text { Govulde Poete }}{462}$} & \multicolumn{2}{|c|}{ Vakente Poute } \\
\hline & & 54 & $(11,6 \%)$ \\
\hline Kaepprovinaio & 280 & 31 & $(10,4 \times)$ \\
\hline Natas & 112 & 7 & $(0,2 \times 4)$ \\
\hline Oranjo-Vrystaed & 170 & 57 & $(33,5 \times)$ \\
\hline Totad & 1040 & 148 & $(14,3 \%)$ \\
\hline
\end{tabular}

Tebel 7

Die dosent-student rotio volgene gevulde poote en moontllke makeimum kepeaholt

\begin{tabular}{|c|c|c|c|c|}
\hline Provinie & $\begin{array}{l}\text { Plod } \\
\text { stand }\end{array}$ & ratio & $\begin{array}{l}\text { Optimale } \\
\text { Kapeaiteit }\end{array}$ & nutio \\
\hline Tranovas & 4888 & $1: 10,70$ & 7496 & $1: 14,50$ \\
\hline Kasprovinale & 2488 & $1: 8,39$ & 3880 & $1: 12,17$ \\
\hline Netel & 800 & $1: 8,03$ & 1320 & $1: 11, \infty$ \\
\hline Orenjo-Vyutach & 1128 & $1: 6,62$ & 1620 & $1: 7,13$ \\
\hline Totad & 8500 & $1: 9,13$ & 14410 & $1: 12,12$ \\
\hline
\end{tabular}

Ammeno: alle dosenteposto govul

Tabol 8

Dle retlo ven verpleegkundlgee tot bevolking

(enkele lende) volgene WGO-norme (Goldby, 1990: 2.1)

\begin{tabular}{|c|c|c|}
\hline Lend & $\begin{array}{l}\text { Verpleeglundipes } \\
10000 \text { Bevolking }\end{array}$ & $\begin{array}{l}\text { Verploopkundiged } \\
\text { bovolkingerutio }\end{array}$ \\
\hline Hongarye & 54 & 1:185 \\
\hline Polend & 53 & 1:187 \\
\hline Joegoedawia & 40 & $1: 250$ \\
\hline Suld-Afrika & 38 & $1: 263$ \\
\hline Chilie & 27 & 1:370 \\
\hline Panama & 28 & 1:3es \\
\hline Fily & 20 & 1:500 \\
\hline Mexiko & 11 & 1:809 \\
\hline
\end{tabular}


Tobol 9

Bereemde takorte in dle openbare sektor 1990 (Coldby, 1990:2.9)

\begin{tabular}{|c|c|c|c|c|}
\hline Indedling & powewe & Voorgendel & $\begin{array}{l}\text { Bereands } \\
\text { tekert }\end{array}$ & x tekort \\
\hline T.P.A. & 10820 & 15700 & 4978 & 32 \\
\hline K.P.A & O 532 & 11315 & 2783 & 25 \\
\hline N.P.A & 4751 & 6017 & 2060 & 30 \\
\hline 0.v.8. & 2582 & 3877 & 1295 & 33 \\
\hline Volkerand & 522 & 889 & 367 & 41 \\
\hline Alowerardodes & 124 & 133 & $\theta$ & 7 \\
\hline Verteennoordigere & 574 & 918 & 344 & 37 \\
\hline N.G.B.O. & 39 & 44 & 5 & 11 \\
\hline Weormag & 687 & 822 & 135 & 16 \\
\hline Totad & 28631 & 40814 & 11003 & 30 \\
\hline
\end{tabular}

Tebol 10

Bereamde tekorte in dle openbare eektor volgene epeslallteltearese 1990 (Goldby, 1990:2.7)

\begin{tabular}{|c|c|c|c|c|c|c|c|c|c|c|c|c|c|}
\hline \multicolumn{2}{|l|}{ Epmalalltelt } & \multicolumn{3}{|c|}{ T.PA. } & \multicolumn{3}{|c|}{ K.PA } & \multicolumn{3}{|c|}{ N.PA. } & \multicolumn{3}{|c|}{ o.v.s. } \\
\hline & & A & B & c & A & B & C & $\mathbf{A}$ & 8 & C & A & $\mathbf{B}$ & c \\
\hline Tecter & $\begin{array}{l}G \\
V\end{array}$ & $\begin{array}{l}836 \\
621\end{array}$ & $\begin{array}{l}255 \\
472\end{array}$ & $\begin{array}{c}32 \\
220\end{array}$ & $\begin{array}{l}297 \\
346\end{array}$ & $\begin{array}{l}102 \\
173\end{array}$ & $\begin{array}{l}19 \\
25\end{array}$ & $\begin{array}{l}273 \\
403\end{array}$ & $\begin{array}{l}70 \\
82\end{array}$ & $\begin{array}{l}6 \\
2\end{array}$ & $\begin{array}{l}114 \\
222\end{array}$ & $\begin{array}{l}52 \\
10\end{array}$ & $\begin{array}{l}3 \\
3\end{array}$ \\
\hline Irtemenet & $\begin{array}{l}a \\
v\end{array}$ & $\begin{array}{l}560 \\
444\end{array}$ & $\begin{array}{l}263 \\
337\end{array}$ & $\begin{array}{c}23 \\
150\end{array}$ & $\begin{array}{l}429 \\
514\end{array}$ & $\begin{array}{c}65 \\
257\end{array}$ & $\begin{array}{l}18 \\
27\end{array}$ & $\begin{array}{l}114 \\
236\end{array}$ & $\begin{array}{l}21 \\
30\end{array}$ & $\begin{array}{l}1 \\
6\end{array}$ & $\begin{array}{l}2003 \\
2002\end{array}$ & $\begin{array}{l}40 \\
93\end{array}$ & $\stackrel{0}{12}$ \\
\hline Peditire & $\begin{array}{l}\mathrm{g} \\
\mathbf{v}\end{array}$ & $\begin{array}{l}729 \\
542\end{array}$ & $\begin{array}{l}300 \\
411\end{array}$ & $\begin{array}{c}28 \\
192\end{array}$ & $\begin{array}{l}386 \\
419\end{array}$ & $\begin{array}{l}117 \\
200\end{array}$ & $\begin{array}{l}28 \\
36\end{array}$ & $\begin{array}{l}241 \\
321\end{array}$ & $\begin{array}{c}151 \\
62\end{array}$ & 1 & $\begin{array}{l}241 \\
143\end{array}$ & $\begin{array}{c}151 \\
46\end{array}$ & 1 \\
\hline Ortor & $\begin{array}{l}a \\
v\end{array}$ & $\begin{array}{l}379 \\
280\end{array}$ & $\begin{array}{l}180 \\
213\end{array}$ & $\begin{array}{c}14 \\
100\end{array}$ & $\begin{array}{l}179 \\
191\end{array}$ & $\begin{array}{l}41 \\
95\end{array}$ & $\begin{array}{l}11 \\
15\end{array}$ & $\begin{array}{l}104 \\
160\end{array}$ & $\begin{array}{l}30 \\
30\end{array}$ & 1 & $\begin{array}{c}43 \\
102\end{array}$ & $\begin{array}{l}13 \\
36\end{array}$ & : \\
\hline Verloekunde & G & $\begin{array}{l}651 \\
631\end{array}$ & $\begin{array}{l}360 \\
460\end{array}$ & $\begin{array}{c}32 \\
224\end{array}$ & $\begin{array}{l}972 \\
861\end{array}$ & $\begin{array}{l}138 \\
480\end{array}$ & $\begin{array}{l}30 \\
51\end{array}$ & $\begin{array}{l}304 \\
558\end{array}$ & $\begin{array}{l}55 \\
76\end{array}$ & $\begin{array}{l}1 \\
0\end{array}$ & $\begin{array}{l}180 \\
243\end{array}$ & $\begin{array}{l}42 \\
76\end{array}$ & $\begin{array}{c}2 \\
14\end{array}$ \\
\hline Pelgletite & $\begin{array}{l}a \\
\end{array}$ & $\begin{array}{l}388 \\
298\end{array}$ & $\begin{array}{l}171 \\
227\end{array}$ & $\begin{array}{c}30 \\
108\end{array}$ & $\begin{array}{l}590 \\
742\end{array}$ & $\begin{array}{l}328 \\
371\end{array}$ & $\begin{array}{l}51 \\
62\end{array}$ & $\begin{array}{l}282 \\
332\end{array}$ & $\begin{array}{l}121 \\
131\end{array}$ & $\begin{array}{l}18 \\
21\end{array}$ & $\begin{array}{c}88 \\
143\end{array}$ & $\begin{array}{l}62 \\
84\end{array}$ & $\begin{array}{l}12 \\
20\end{array}$ \\
\hline Cemcenakep & $\begin{array}{l}G \\
V\end{array}$ & $\begin{array}{l}1448 \\
1297\end{array}$ & $\begin{array}{l}618 \\
805\end{array}$ & $\begin{array}{c}70 \\
481\end{array}$ & $\begin{array}{l}623 \\
554\end{array}$ & $\begin{array}{l}107 \\
277\end{array}$ & $\begin{array}{l}13 \\
26\end{array}$ & $\begin{array}{l}182 \\
212\end{array}$ & $\begin{array}{l}67 \\
78\end{array}$ & $\begin{array}{l}10 \\
17\end{array}$ & $\begin{array}{l}272 \\
314\end{array}$ & $\begin{array}{l}143 \\
130\end{array}$ & $\begin{array}{l}31 \\
31\end{array}$ \\
\hline
\end{tabular}

A - Profecedorelo verplecegkundige

B - Senior verpleogk undige

C = Hoot verpleang undoe

G - Goodpetteurdo poato

V. Voorpentelde poete

Tabol 11

Bereemde atudento-uitveleyfor

(Goldby, 1990: 2.10)

\begin{tabular}{|c|c|}
\hline Jaer & Uitvaloytor \\
\hline Eerate & $30 \%$ \\
\hline Tweende & ex \\
\hline Denclo & $2 x$ \\
\hline veringt & $1 \%$ \\
\hline Gemidideld & $37 x$ \\
\hline
\end{tabular}


Tabel 12

Ceproplkteerde bovolkingegroel (Goldby, 1990: 4.2)

\begin{tabular}{|c|c|c|c|c|c|}
\hline Jeer & Antre & PBA Swarte & Kleurlinge & Blankeo & Toted \\
\hline 1800 & $\infty$ & 11601 & 3221 & 50020 & 21110 \\
\hline 1806 & 1028 & 13052 & 3504 & 5233 & 23433 \\
\hline 2000 & 1114 & 15873 & 3757 & 5418 & 20802 \\
\hline 2000 & 1127 & 10112 & 3805 & 5452 & 20400 \\
\hline 2010 & 1140 & 16663 & 3861 & 5482 & 27035 \\
\hline
\end{tabular}

Gatale in 000

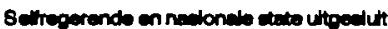

Tabol 13

Goprojakteerde eonvreeg na verpleegkundlgoe

(reảb jearlikee atudento-utteet) volgens bevolklngegrool (AKQ, 1990;)

\begin{tabular}{|c|c|c|c|c|c|}
\hline $1000-1804$ & 1008 & $1005-1800$ & 2000 & $2000-2004$ & 2005 \\
\hline 2500 & 12005 & 2640 & 13200 & 2803 & 13413 \\
\hline
\end{tabular}

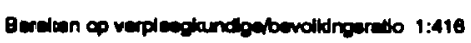

